\title{
Comparison of serum 1,25-dihydroxycholecalciferol concentrations in rheumatoid arthritis and osteoarthrosis
}

\author{
H. A. BIRD,${ }^{1}$ V. WRIGHT, ${ }^{1}$ U. HENNES, ${ }^{2}$ AND E. THEISS ${ }^{2}$ \\ From the ${ }^{1}$ Rheumatism Research Unit, University Department of Medicine, General Infirmary at Leeds, \\ England, and ${ }^{2}$ Hoffman-La Roche and Co. Ltd., Basle, Switzerland
}

SUMMARY We have previously compared 25-hydroxycholecalciferol levels in the serum of patients with osteoarthrosis and rheumatoid arthritis, finding no significant difference between the circulating levels of this hormone. We have now estimated 1,25-dihydroxycholecalciferol levels on stored sera from the same groups of patients and found no significant difference in the levels of this hormone between the 2 groups. The osteopenia that distinguishes rheumatoid arthritis from osteoarthrosis is not the result of altered levels of systemic $25 \mathrm{OHD}_{3}$ or of $1,25(\mathrm{OH})_{2} \mathrm{D}_{3}$. Local factors may be more important in its pathogenesis.

We have recently studied 25 -hydroxycholecalciferol levels in the serum of patients with osteoarthrosis and with rheumatoid arthritis. ${ }^{1}$ We showed no significant alteration in circulating $25-\mathrm{OHD}_{3}$ levels that might have accounted for the generalised juxta-articular osteopenia that differentiates rheumatoid arthritis from osteoarthrosis. However, it remains a possibility that levels of $1,25(\mathrm{OH})_{2} \mathrm{D}_{3}$, the more active metabolite synthesised by the kidney from $25-\mathrm{OHD}_{3}$, might be impaired in rheumatoid disease, even though the renal involvement seen in other connective tissue disorders is not a characteristic of rheumatoid arthritis. We have therefore estimated $1,25(\mathrm{OH})_{2} \mathrm{D}_{3}$ levels in stored. sera from the same group of patients previously described.

\section{Patients and methods}

We studied 60 consecutive patients admitted to the Royal Bath Hospital, Harrogate. Thirty had classical or definite rheumatoid arthritis (ARA criteria) and 30 had osteoarthrosis (moderate or severe osteoarthrotic changes on $x$-ray examination, normal erythrocyte sedimentation rate (ESR), and negative serology for rheumatoid factor). Both groups were bled in the fasting state concurrently between

Accepted for publication 29 April 1981.

Correspondence to Dr H. A. Bird, Clinical Pharmacology Unit, Royal Bath Hospital, Cornwall Road, Harrogate HG1 2PS.
November and December 1978 on the first day of admission to hospital. Blood was measured for full blood count, ESR, calcium, liver function tests, rheumatoid factor, and plasma $1,25(\mathrm{OH})_{2} \mathrm{D}_{3} .{ }^{2} \mathrm{~A}$ dietary survey was made and exposure to sunlight quantified by a questionnaire and simple scoring system. ${ }^{3}$ Patients in the 2 groups were well matched for age, sex, duration of arthritis, exposure to sunlight, and dietary vitamin $\mathrm{D}$ intake (Table 1 ). Details of drug treatment, including nonsteroidal antiinflammatory agents (NSAIA), for both groups are also shown in Table 1 .

Table 1 Comparison of patients with osteoarthrosis and patients with rheumatoid arthritis (means $\pm S D$ )

\begin{tabular}{lll}
\hline & $\begin{array}{l}\text { Osteoarthrosis } \\
(n=30)\end{array}$ & $\begin{array}{l}\text { Rheumatoid arthritis } \\
(n=30)\end{array}$ \\
\hline $\begin{array}{l}\text { Mean age (years) } \\
\text { Sex (M:F) }\end{array}$ & $63 \cdot 3 \pm 15 \cdot 0$ & $60 \cdot 8 \pm 9 \cdot 5$ \\
$\begin{array}{l}\text { Mean duration of arthritis } \\
\text { (years) }\end{array}$ & $12: 22$ & $10: 20$ \\
$\begin{array}{l}\text { Mean sunlight exposure score } \\
\text { Mean dietary vitamin D intake }\end{array}$ & $25 \cdot 1 \pm 10 \cdot 5$ & $13 \cdot 7 \pm 9 \cdot 8$ \\
$\quad$ (IU/day) & $240 \pm 185$ & $23 \cdot 2 \pm 11 \cdot 4$ \\
$\begin{array}{l}\text { No. receiving one analgesic } \\
\text { No. receiving 2 analgesics }\end{array}$ & 14 & $234 \pm 154$ \\
$\begin{array}{l}\text { No. receiving one NSAIA } \\
\text { No. receiving more than one }\end{array}$ & 17 & 18 \\
$\quad$ NSAIA & 3 & -19 \\
No. receiving Myocrisin & - & 7 \\
No. receiving penicillamine & - & 10 \\
\hline
\end{tabular}

NSAIA $=$ Nonsteroidal anti-inflammatory agent. Myocrisin $=$ sodium aurothiomalate. 


\section{Results}

There was no significant difference between the mean serum, $1,25(\mathrm{OH})_{2} \mathrm{D}_{3}$ level for the osteoarthrosis (OA) group $(26 \cdot 1 \mathrm{pg} / \mathrm{ml})$ or for the rheumatoid arthritis (RA) group $(27.9 \mathrm{pg} / \mathrm{ml})$. A reduction in $1,25(\mathrm{OH})_{2} \mathrm{D}_{3}$ with age was seen in both groups and mirrored the reduction in $25-\mathrm{OHD}_{3}$ previously observed. No significant differences were seen between sexes $(\mathrm{RA}, \mathrm{M} / \mathrm{F}=29 \cdot 6 / 27 \cdot 0 \mathrm{pg} / \mathrm{ml}$; $\mathrm{OA}, \mathrm{M} / \mathrm{F}=26 \cdot 6 / 25 \cdot 9 \mathrm{pg} / \mathrm{ml})$. When patients with RA were divided into those receiving steroids $(\mathrm{n}=$ 17) and those not receiving steroids $(n=13)$, no significant difference was seen in $1,25(\mathrm{OH})_{2} \mathrm{D}_{3}$ levels (mean $=29.2 \mathrm{pg} / \mathrm{ml}$ and $24.7 \mathrm{pg} / \mathrm{ml}$ respectively). $1,25(\mathrm{OH})_{2} \mathrm{D}_{3}$ levels did not correlate either with articular index or with ESR in either group. $1,25(\mathrm{OH})_{2} \mathrm{D}_{3}$ levels correlated slightly better with sunlight exposure than with dietary vitamin $\mathrm{D}$ intake.

\section{Discussion}

$1,25(\mathrm{OH})_{2} \mathrm{D}_{3}$ levels mirrored $25-\mathrm{OHD}_{3}$ levels in this group of patients, confirming that hydroxylation of $25-\mathrm{OHD}_{3}$ in the kidney is independent of the nature of the disease. Since almost all $1,25(\mathrm{OH})_{2} \mathrm{D}_{3}$ levels were within the normal range for the age group, it is unlikely that there is any substantial impairment of vitamin D metabolism in rheumatoid arthritis. We have found no evidence of a dependence of vitamin $D$ metabolism on steroid intake in the rheumatoid group, and our earlier suspicion of a slight tendency for patients with RA and a high ESR to have lower $25-\mathrm{OHD}_{3}$ levels has not been confirmed on analysis of $1,25(\mathrm{OH})_{2} \mathrm{D}_{3}$ levels.

The findings of this and our earlier study support the hypothesis that local factors, possibly prostaglandins, are more important than systemic factors in producing the osteopenia characteristic of rheumatoid joints.

\section{References}

1 Bird H A, Peacock M, Storer J H, Wright V. Comparison of serum 25-OH vitamin D concentrations in rheumatoid arthritis and osteoarthrosis. Br Med J 1980; 280: 1416.

2 Mallon J P, Hamilton J G, Nauss-Karol C, et al. An improved competitive protein binding assay for 1,25 dihydroxyvitamin $D$. Arch Biochem Biophys 1980; 201: 277-85.

${ }^{3}$ Hodkinson H M, Round P, Stanton B R, Morgan C. Sunlight, vitamin D, and osteomalacia in the elderly. Lancet 1973; ii: 910-2. 